\title{
MURAL DALAM PAPARAN MEDIA DAN PEMBELAJARAN SOSIAL BAGI MASYARAKAT KAMPUNG KOTA
}

\author{
Deddy Award Widya Laksana ${ }^{1}$ dan Bernardus Andang Prasetya Adiwibawa² \\ 1,2Universitas Dian Nuswantoro
}

\begin{tabular}{|c|c|c|}
\hline Received: 15 Januari 2018 & Revised: 22 Februari 2018 & Accepted: 25 Februari 2018 \\
\hline
\end{tabular}

\begin{abstract}
Abstrak: Mural, cukup efektif memberi dampak melalui pesan-pesan yang tergambar. Inspirasinya didapat dari karya sejenis yang lebih dulu ada dan digerakkan juga oleh situasi sosial-budaya dan politik yang melingkupi suatu masyarakat. Kajian ini adalah tentang variasi wimba yang digunakan dalam menyampaikan pesan mengenai nilai luhur dalam masyarakat dan bagaimana khalayak pengamatnya menanggapi wimba tersebut. Kajian dilakukan dengan pendekatan deskriptif kualitatif terhadap mural di kampung kota dengan metode utama observasi dan wawancara.
\end{abstract}

Kata kunci: kampung kota, komunikasi, mural, paparan media, pembelajaran sosial.

Abstract: Murals, are quite effective in giving some effects through is illustrated messages. The inspiration is derived from similar works which exist and driven by the socio-cultural and political situation. This study is about the variation of the images used in conveying the message of noble value in society and how its audiences respond to the image. The study is conducted in qualitative descriptive approach along with observation and interview.

Keywords: urban kampoong, communications, mural, media exposure, social learning.

\section{PENDAHULUAN}

Mural, gambar atau lukisan di atas media dinding yang relatif luas, cukup efektif untuk memberi dampak pada siapa saja yang melihatnya, melalui pesanpesan yang tergambar (Endriawan, dkk 2017). Kesimpulan itu diungkapkan oleh Endriawan dkk. dalam kajiannya tentang mural di dua panggung yang berbeda, di Sekolah Menengah Pertama Istiqomah, Bandung dan Markas Batalyon III/Yudha Wyogrha, Zeni Tempur, Dam III/ Siliwangi, Bandung. Hal ini seperti menegaskan kajian yang dilakukan Zahra dan Yeni (2009) yang menyimpulkan bahwa mural

${ }^{1}$ Program Studi Animasi, Universitas Dian Nuswantoro, e-mail: deddyawardwidyalaksana@gmail.com 2Program Studi DKV, Universitas Dian Nuswantoro, e-mail: andangprast@dsn.dinus.ac.id 
memberi dampak bagi kehidupan masyarakat sebagai hiburan, ajang kreativitas, pengingat hal-hal positif, dan memperindah kota. Dari sisi inspirasi terciptanya karya dekoratif kota, termasuk mural, Fernanda \& Kusuma (2017) mengatakan bahwa salah satunya adalah keberadaan karya sejenis di kota-kota lain di dunia.

Pendapat yang senada dikemukakan oleh walikota Semarang, Hendrar Prihadi, dalam sebuah wawancara dengan media, mengenai keberadaan Kampung Pelangi yang terinspirasi oleh salah satu sudut di Rio de Janeiro (Purbaya, 2017). Alasan lain terciptanya mural atau karya dekoratif kota, juga dipengaruhi oleh situasi yang melingkupi suatu masyarakat. Dalam kajiannya tentang tiga kampung kota; Kali Code (Semarang), Jodipan (Malang) dan Kampung Pelangi Wonosari (Semarang), Adiwibawa (2017) menunjukkan bahwa terciptanya karya dekoratif di tiga kampung itu terkait erat dengan dinamika sosial-budaya-politik yang berkembang saat itu. Kontestasi politik, alternatif pemecahan masalah dan inisiasi personal atau kelompok dalam dinamisnya situasi sosial menjadi faktor yang tidak bisa diabaikan.

Kondisi di atas memberikan wawasan bahwa karya dekoratif kota, khususnya mural, dapat digunakan sebagai sarana untuk mendidik masyarakat akan nilai-nilai luhur yang berpotensi tergerus karena perkembangan zaman dan dinamika masyarakat. Dalam hubungannya dengan konsep wimba dalam karya rupa, wimba semacam apa yang sering dipakai dalam mural dan bagaimana khalayak pengamat mural menanggapi wimba tersebut, menjadi fokus kajian dalam tulisan ini.

\section{METODE PENELITIAN}

Dengan fokus pada wimba dan bagaimana tanggapan khalayak atas wimba yang ada, maka metode utama dalam kajian ini adalah observasi dan 
wawancara. Unit kajian adalah varian-varian wimba yang ada pada dua buah kampung di Semarang; Kampung Batik dan Kampung Pelangi Wonosari.

Alasan dipilihnya kedua kampung ini adalah karena keduanya merupakan kampung yang ikonik, penuh dengan dekorasi mural maupun sekedar komposisi warna tanpa wimba. Keduanya dengan demikian, berbeda dengan kampungkampung yang lain secara rupa dalam kategori kampung tematik kota Semarang yang dicanangkan oleh pemerintah Kota Semarang.

Analisis yang digunakan dalam kajian ini adalah deskriptif kualitatif. Subrata (2012) menggunakan analisis yang sama untuk mengkaji, memahami dan mendekonstruksi ideologi yang tersembunyi di balik komodifikasi seni pertunjukan barong di Gianyar, Bali. Sama dengan yang dilakukan Subrata, alat analisis ini dalam kajian ini juga akan digunakan untuk mengkaji dan memahami fenomena karya mural di tengah masyarakat secara menyeluruh.

\section{HASIL DAN DISKUSI}

\section{Paparan Media dan Pembelajaran Sosial}

Beberapa teori yang digunakan dalam kajian ini adalah teori tentang paparan media (media exposure) dan secara khusus social learning theory. Paparan media, menurut Rakhmat yang dikutip oleh Setiyawan (2013) adalah seberapa sering orang membaca, menonton atau mendengar melalui media tertentu dalam jumlah atau frekuensi tertentu. Sementara menurut Ostrov et al.(2013) selain jumlah paparan, efek dari media juga terkait dengan isi yang ada dalam media tersebut.

Mural sebagai obyek kajian adalah media dalam konteks apa yang dikemukakan Setyawan dan Ostrov di atas. Sementara itu wimba yang ada dalam mural sebagai unit kajian, adalah isi sebagaimana yang dimaksud Ostrov. Wimba 
adalah konsep yang diciptakan oleh Primadi Tabrani (2012) yang adalah sulih bahasa dari istilah Inggris, image.

Mural sebagai media dan wimba sebagai isi media, dalam hubungan dengan konstruksi pengetahuan secara sosial, didekati dalam konsep pembelajaran sosial. Teori belajar sosial yang dikembangkan oleh Bandura, sebagaimana dikutip oleh Fithri (2014) menyebutkan bahwa seseorang belajar dalam dan melalui lingkungan dimana dia tinggal. Proses itu dilakukan melalui pemodelan, yaitu pengamatan akan pengalaman orang lain, dan pengamatan melalui fenomena lingkungan sekitar, fisik maupun sosial.

Mural adalah bagian dari lingkungan fisik yang terbentuk juga dari manipulasi rupa yang inspirasinya bisa dari banyak hal. Paparan mural sebagai media dan wimba sebagai isi medianya, tentu saja akan menjadi model pula bagi seseorang untuk membentuk pengetahuannya.

\section{Mural Kampung Batik dan Kampung Pelangi}

Mural di Kampung Batik dan Kampung Pelangi, keberadaannya tersebar di beberapa sudut kampung. Namun ada perbedaan yang nampak antara mural di masing-masing kampung. Salah satu faktor yang menjadi pembeda adalah lingkungan fisik yang berbeda antara kedua kampung.

Kampung pelangi berada di lereng Bukit Gunung Brintik, sebuah bukit di tengah kota Semarang, yang berjarak kurang dari satu kilometer dari kawasan Tugu Muda. Sebaliknya Kampung Batik, terletak agak di tepi kota, tepatnya di sebelah timur kawasan Kota Lama Semarang.

Karena letak geografisnya, Kampung pelangi lebih nampak menyolok dari pandangan siapa saja yang melewati Jl. dr. Soetomo, salah satu jalan protokol yang menghubungkan kawasan Tugu Muda dengan kawasan Semarang bagian 
atas. Warna-warni yang menyolok, mendominasi tampilan rupa kampung, menyembunyikan variasi mural di dalamnya.

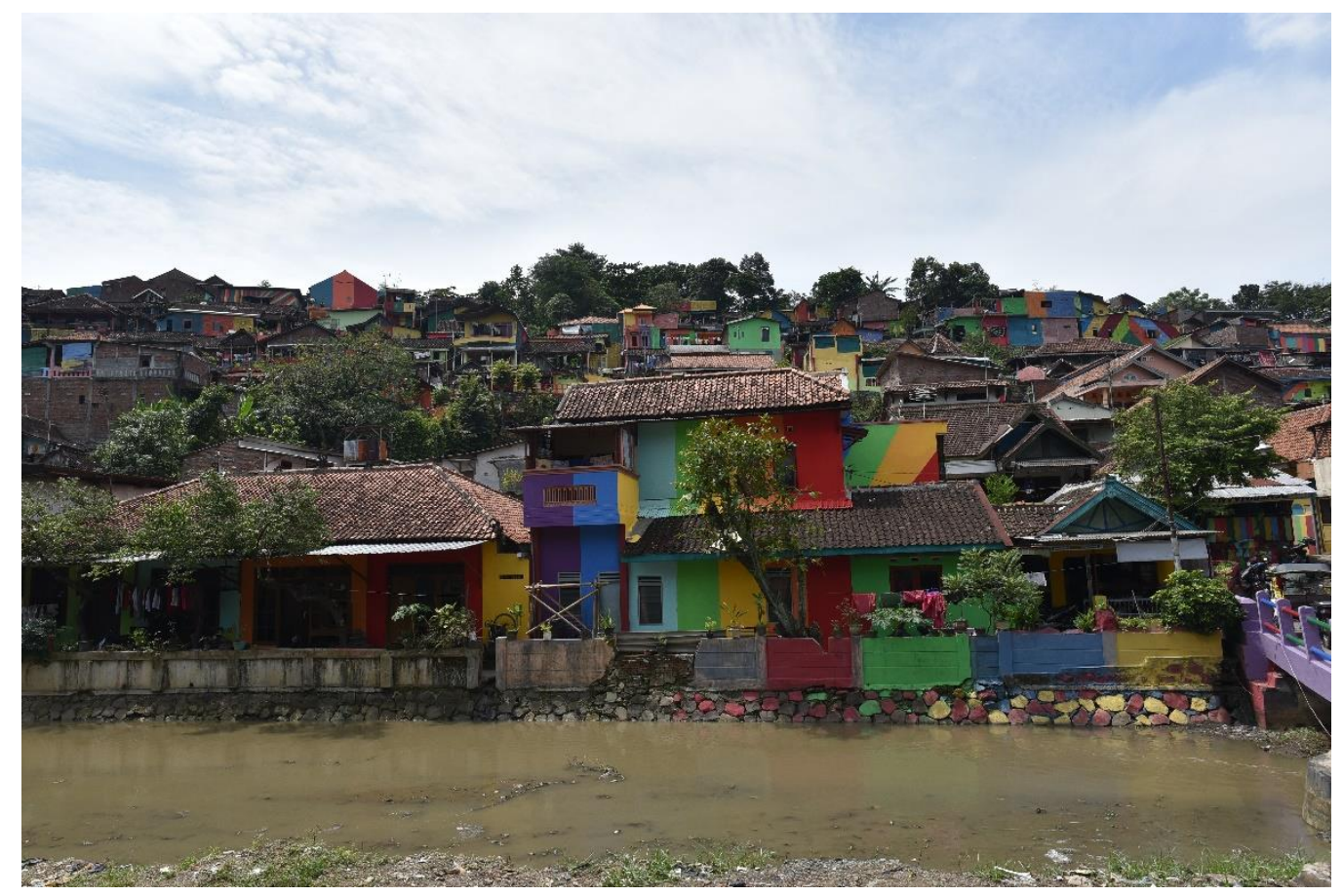

Gambar 1 : Tampilan rupa kampung pelangi dari Jl. dr. Soetomo -

(Sumber : Laksana \& Adiwibawa, 2018)

Kampung Batik, berkebalikan dengan Kampung Pelangi. Lokasinya di dataran, dan berada di sisi timur kawasan Kota Lama, membuat orang yang baru pertama kali ke Semarang, tidak mudah menemukannya. Di salah satu ruang terbuka umum nyaris di ujung kampung yang berada di Jl. MT. Haryono, memang ada identitas kampung ini, tetapi karena dibuat dari bahan logam yang memantulkan citra di sekitar lingkungan, membuat tulisannya kurang terbaca. 


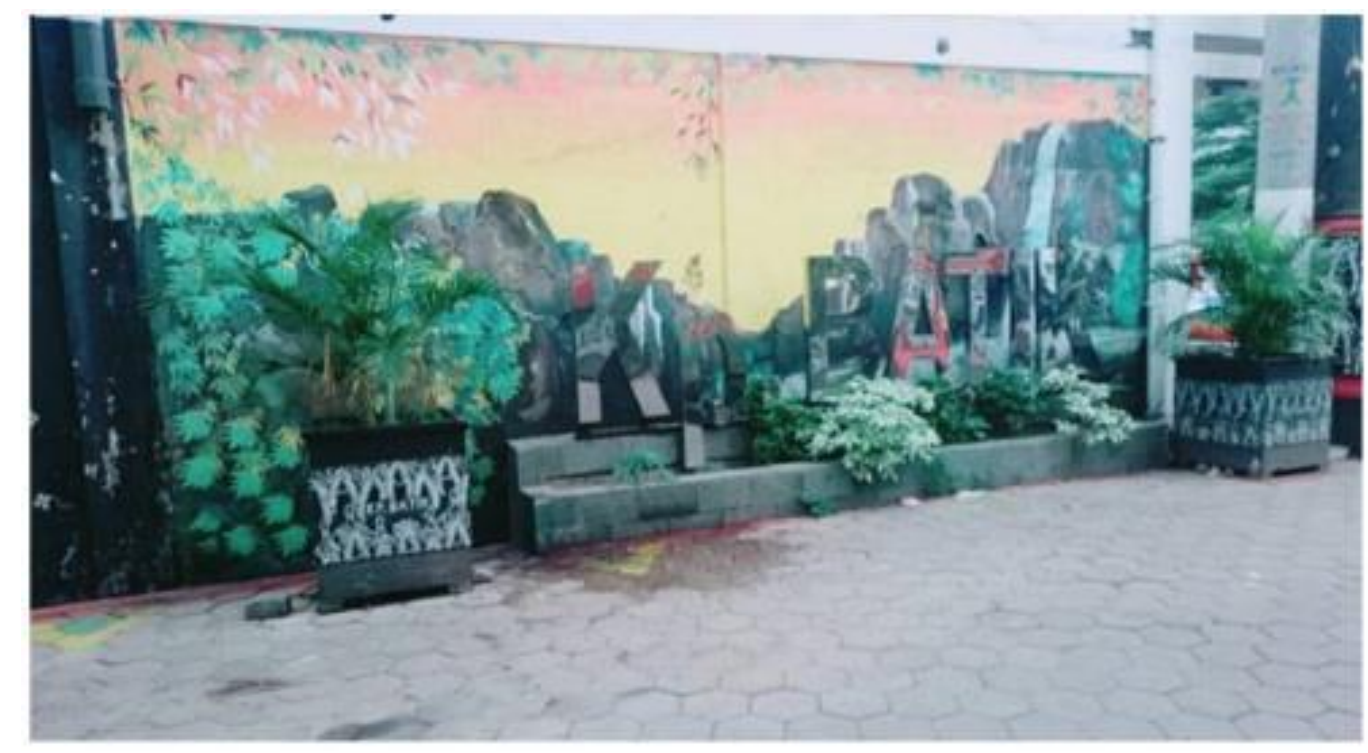

Gambar 2: Mural di ruang terbuka di ujung kampung di belakang Giant Letter Sumber: Ahmad Alim dkk.

Kampung Pelangi, seperti yang disebut di atas, dominan dengan dekorasi warna-warni yang ditorehkan dalam bentuk blok-blok bidang dari dinding hingga atap. Nyaris tidak ada yang membedakan antara rumah yang satu dengan rumah yang lain jika dilihat secara sepintas dari luar. Blok-blok warna yang ada menjadi suatu kesatuan yang tidak berdiri sendiri. Namun, saat berada di dalam kampung, melihat secara lebih detail, perbedaan itu tergambar dari mural yang ada. Bisa dikatakan, tidak ada karakter yang dominan dalam wimba pada mural tersebut. Penduduk secara bebas menentukan wimba semacam apa yang ingin dibuat. 

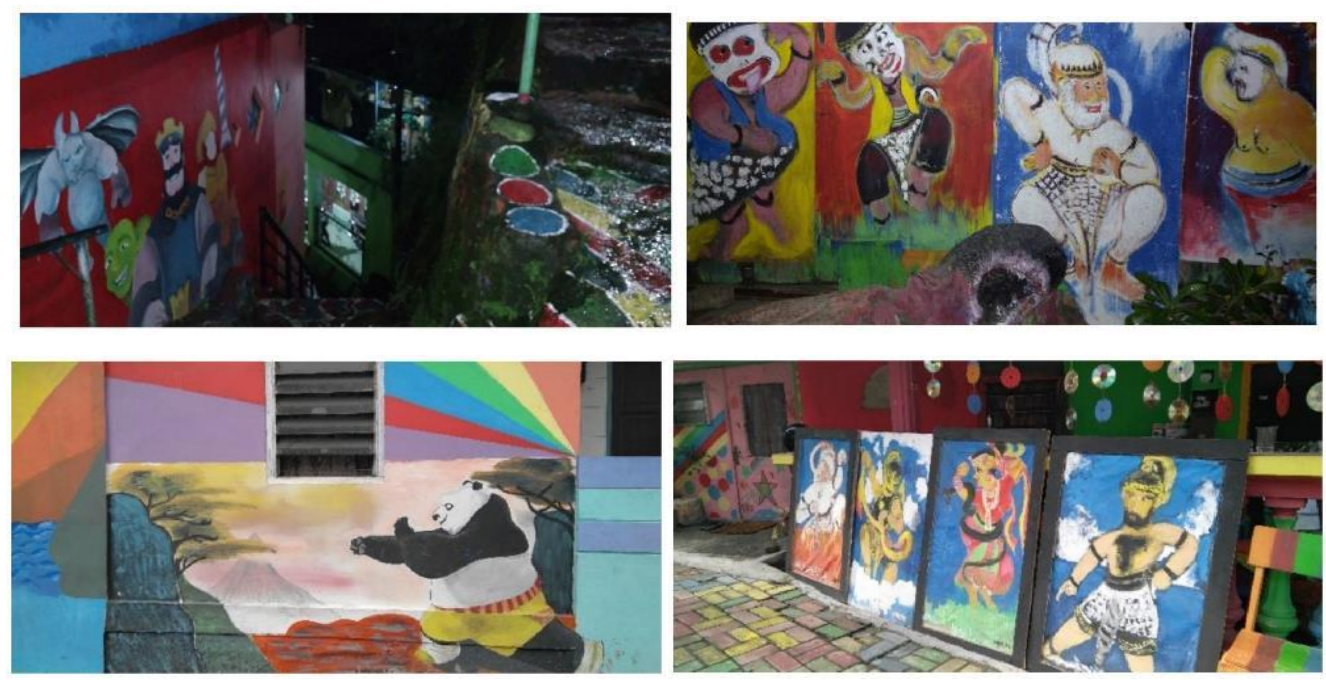

Gambar 3 : Variasi wimba di beberapa dinding rumah Kp. Pelangi

Sumber : Genio Haidar dkk.

Keadaan yang berbeda dimiliki Kampung Batik. Berada di belakang pertokoan yang nampak sama dengan pertokoan lain di Kota Semarang, kampung ini justru memiliki beberapa karya mural yang dominan. Di salah satu gang yang cukup panjang, diapit dua buah tembok, ada karya mural yang dapat dikatakan paling menyolok. Mural itu karya Ignatius Luwiyanto, seorang guru, yang adalah pendatang dari Yogyakarta. Karya yang diberi nama Adeging Kutho Semarangitu dibuat dalam format seperti wayang beber. Selain mural tersebut yang, boleh dikatakan, ikonik untuk Kampung Batik, ada beberapa mural yang juga menarik di sini, misalnya yang ada di salah satu ujung salah satu gang yang dominan dengan wimba floral. 

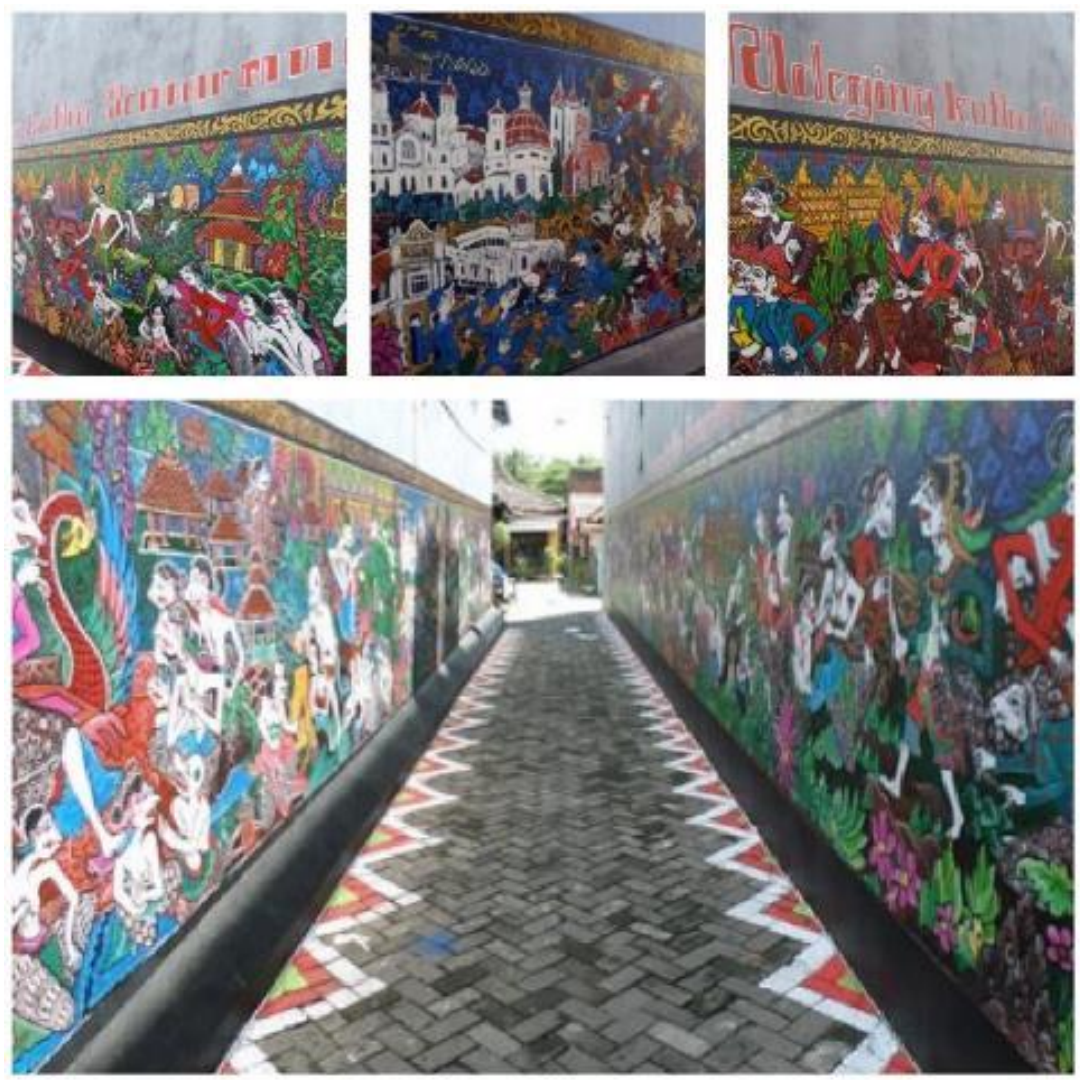

Gambar 4 : Mural Adeging Kutho Semarang karya Ign. Luwiyanto Sumber : Ahmad Ma'arif Al-Akhir dkk

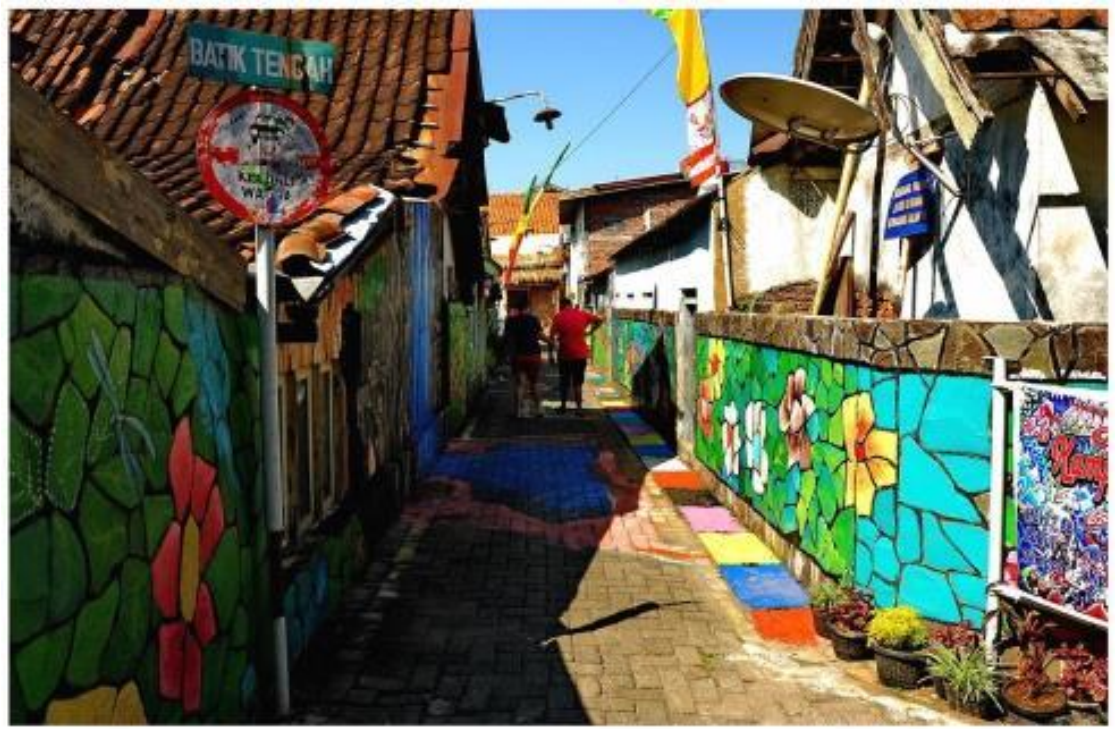

Gambar 5: Mural berwimba tumbuhan di gang kampung Batik Tengah -

Sumber: Aulia Ananda dkk. 


\section{Variasi Wimba pada Mural Kampung Batik dan Kampung Pelangi}

Dari pengamatan di kedua kampung, menunjukkan bahwa ada beragam variasi wimba di mural yang ada. Sebagian wimba adalah karakter wayang, mulai dari kesatria hingga punakawan, sebagian lagi menggambarkan tokoh kartun anak-anak, binatang-binatang indah dan tumbuh-tumbuhan, juga karakter fantasi.

Wimba wayang, dengan bentuk yang lebih serius, meniru karakter wayang kulit, nampak mendominasi mural di Kampung Batik. Kedekatan dengan citra kampung sebagai tempat beberapa produsen batik, nampaknya berpengaruh pada penggambaran wimbanya. Hal ini ditambah dengan demografi kampung yang didominasi oleh keluarga-keluarga dewasa.

Gambaran wimba yang lebih variatif dan berkarakter kanak-kanak nampak mendominasi Kampung Pelangi. Faktor demografis dengan masih banyaknya keluarga muda dan keragaman mata pencaharian ditambah potensi besarnya sebagai kunjungan wisata sangat mempengaruhi tampilan wimbanya. Mural di Kampung pelangi mengandung wimba yang lebih ceria sepadan dengan warna-warni tampak rupa kampung.

Meski berbeda variasi, nampaknya wimba yang dipakai dalam mural di kedua kampung menunjukkan kedekatan antara seniman dan pengamat muralmurat itu. Wayang, apakah karakter itu digambarkan ala wayang kulit, wayang beber atau wayang orang, adalah wimba yang sangat dekat dengan budaya Jawa, tempat pijakan budaya kedua kampung. Sementara wimba dengan karakter kartun anak-anak adalah wimba yang dekat dengan dunia anak. Oleh karenanya, wimba-wimba semacam ini efektif digunakan untuk menyampaikan pesan keutamaan secara sosial kepada apakah kalangan dewasa maupun anak-anak. 
Penggunaan wimba yang dekat secara sosiologis dan kultural semacam ini, niscaya digunakan dalam berbagai desain yang berkaitan dengan kedua kampung atau bagian wilayah kota secara lebih luas. Berbagai desain lingkungan misalnya sistem tanda (signage system) bisa diolah sedemikian rupa sehingga menarik sekaligus mampu menanamkan nilai keutamaan bagi banyak kalangan.

\section{KESIMPULAN}

Paparan di atas menunjukkan bahwa bagaimanapun bervariasinya mural, wimba yang digunakan di dalamnya sangat dekat dengan khalayak pengamatnya. Kedekatan itu dipertimbangkan oleh para artis dari aspek sosiologis maupun kulturalnya. Pendekatan seni dan desain semacam ini efektif membawa pesan nilai keutamaan suatu masyarakat sekaligus melestarikan khasanah budaya yang berkontestasi ketat dengan perkembangan jaman.

Pada sisi lain, pendekatan penciptaan wimba yang mempertimbangkan aspek sosiologis dan kultural dapat menjadi inspirasi dalam pengembangan desain lainnya. Desain sistem tanda, instalasi lingkungan, media komunikasi visual dan desain lain yang berkaitan dengan kampung atau bagian kota lain, niscaya akan semakin efektif menyampaikan pesan nilai keutamaan dengan pendekatan serupa.

\section{PERNYATAAN PENGHARGAAN}

Ucapan terima kasih dan penghargaan diberikan kepada Bp. Ign. Luwiyanto, masyarakat Kampung Pelangi dan Kampung Batik Semarang, selaku narasumber, para mahasiswa yang membantu mendokumentasikan data lapangan, serta para sejawat yang tidak bisa disebutkan satu persatu atas bantuan penyusunan hingga terbitnya artikel ini. 


\section{DAFTAR PUSTAKA}

Adiwibawa, B Andang P. 2017. Kampung Pelangi: The Reflection of National Value. dalam International Conference on Arts and Culture 2017 (pp 87-94). Fakultas Bahasa dan Seni, Universitas Negeri Semarang.

Bandura, A., \& Doll, E. B. (2005). Teori Belajar Sosial. BUKU PERKULIAHAN, 101.

Endriawan, D., Maulana, T. A., \& Sadono, S. 2017.Mural sebagai Media Pendidikan dan Pengabdian Masyarakat. dalam Seminar Nasional Seni dan Desain (pp. 482-485). State University of Surabaya.

Fithri, Rizma. 2014. Psikologi Belajar. Buku Perkuliahan. Prodi Psikologi, Fakultas Dakwah dan Ilmu Komunikasi, Universitas Islam Negeri Sunan Ampel, Surabaya. (pp. 101-110)

Ostrov, J. M. et.al. 2013. Evaluating the effect of educational media exposure on aggression in early childhood. Journal of Applied Developmental Psychology, 34(1), (pp. 38-44).

Purbaya, Angling Adhitya. 2017. "Ini Cerita di Balik Kampung Pelangi" available at: https://travel.detik.com/travel-news/d-3505071/ini-cerita-di-balikkampung-pelangi-semarang-yang-tengah-hits

Setiyawan, A. 2013. Hubungan antara Frekuensi dan Durasi Terpaan Film Porno dengan Sikap Remaja Laki-laki terhadap Pelecehan Seksual. Calyptra, 2(1), (pp 1-11).

Subrata, I. W. 2012. Komodifikasi Seni Pertunjukan Barong di Banjar DenjalanBatur Desa Batubulan, Gianyar, Bali. disertasi, Program Doktor, Program Studi Kajian Budaya, Program Pascasarjana, Universitas Udayana.

Sudrajat, A. (2008). Pengertian pendekatan, strategi, metode, teknik, taktik, dan model pembelajaran. Online (http://smacepiring. wordpress. com).

Tabrani, Primadi. 2012. Bahasa Rupa, cetakan ke 3, Bandung, Penerbit Kelir

Zahra, D. F., \& Yeni, R. Ida. 2009. Seni Mural Sebagai Media Pendidikan Guna Mencegah vandalisme Di SMA Negeri 5 Yogyakarta., Pelita, 4(1). 